\title{
Nine Layer Pyramid Model Questionnaire for Emotional Intelligence
}

\author{
https://doi.org/10.3991/ijoe.v17i07.22765
}

\author{
Athanasios Drigas ${ }^{(凶)}$, Chara Papoutsi \\ N.C.S.R. 'Demokritos', Athens, Greece \\ University of the Aegean, Information and Communication Systems Engineering Department, \\ Samos, Greece \\ drait.demokritos.gr
}

\begin{abstract}
Emotional intelligence is significant, and it is an integral key to successful intrapersonal and interpersonal relationships. High emotional intelligence strengthens individuals with additional abilities and skills necessary in personal and working life. This study aims to develop Nine Layer Pyramid Model Questionnaire, a reliable and valid measurement instrument of emotional intelligence, based on the theoretical nine-layer pyramid model of emotional intelligence which illustrates hierarchically the abilities and skills that people need to possess to reach the top of emotional intelligence. Models of emotional intelligence and literature on it were investigated, and tool with 81 items was developed. The question items were in full correlation with the levels of the pyramid model. Data were collected through self-reports from 520 teachers from primary and secondary school grade. Results via statistical analysis indicated that the scale is a reliable and valid instrument in measuring emotional intelligence and showing which level they have achieved better and at which level improvements are needed.
\end{abstract}

Keywords - Emotional intelligence, measurement of emotional intelligence, nine-layer pyramid model, validity, reliability

\section{Introduction}

\subsection{Emotional intelligence, models, and measurements}

Emotional Intelligence or EQ has become extremely popular both in the scientific world and in the public. Emotional intelligence has been linked to a wealth of research, many of them showing its positive correlations in many areas such as academic achievement [1,2] psychological well-being [3,4], stress [5,6], personality [7], social relationships [8,9], workplace [10,11] leadership [12,13], health [14], education [15].

Despite its higher impact, there is much debate about the content of this concept, its competencies, and its best way to measure it. Emotional intelligence is not a new term, and many researchers have tried to reformulate older and more recent theories to better approach it. Furthermore, multiple models of EQ and measurements of it have been advocated. Despite the different perspectives, emotional intelligence seems to offer useful insights into the convoluted and complex inner worlds of human beings. 
Research on emotional intelligence has been divided into three distinct areas of perspectives in terms of conceptualizing emotional competencies and their measurements. There is the ability EI model [16], the mixed models [17-19], and the trait EI model [20,21].

The difference between the EI models stems from the way of conceptualization, measurement, and assessment of the EI. Various psychometric tools have been developed to measure emotional intelligence, which are based on the theoretical models. These psychometric tools are classified into three categories; 1) Self-reports: These are suggestions-statements that are granted to those interested in the form of a questionnaire. The participants are carefully reading the suggestions-statements and are asked to choose the degree to which they agree or disagree with what it is presented in the sentence-declaration according to the five-point or seven-point Likert scale [22]. The self-report method is mainly used by mixed models and trait models. 2) Other Reports: These are again suggestions-statements in the form of a questionnaire. The difference is that in this case other people (from the familial and social environment) are asked to complete the sentences-statements that concern the abilities and characteristics of a person that they know. A representative questionnaire is that of Goleman and Boyatzis. 3) Objective measurement of skills: That measurement involve answers to questions or solutions to problems and scored according to the answer solution given since each question - problem has only one correct answer and the answers - solutions are sorted and are calibrated in terms of their correctness by experts. Ability models mainly belong to this category. Perez et al. (2005), present a complete overview of ability EI measures and trait - mixed EI measures, along with basic information about their reliability, validity and factor structure provided [23].

Recent worth noting efforts have also been made to develop reliable and valid measurement instruments of emotional intelligence. One to mention is TIE [24], an ability test and TYEIS [25], a test based on mixed model.

The aim of this paper is to introduce a new instrument, labeled the Nine Layer Pyramid Model Questionnaire for Emotional Intelligence. The development of this questionnaire is attributed to our belief that it is legitimate and worthwhile to construct new questionnaires in the scientific world to assess emotional intelligence based on a theoretical model. The already constructed questionnaires of any kind are remarkable and are the best springboard for the creation of new ones for research and diagnostic purposes. It is encouraging to develop and validate measuring instruments considering different cultural groups and cultures as these two factors influence the experience and expression of emotions [26].

\section{Nine Layer Pyramid Model Questionnaire of Emotional Intelligence: Creation, Competencies, and Objectives}

In Drigas \& Papoutsi (2018) a thoroughly presentation was made of the pyramid of Emotional Intelligence as an attempt to create a new layer model based on emotional, cognitive, and metacognitive skills [27].

The idea was stemmed from the previous important theories of emotional intelligence. The model of emotional intelligence has been created with a distinct classification. Each level includes specific skills that the individual must have acquired to possess 
that level of emotional intelligence and then be able to ascend to the next higher level. It is a methodology for the further development and evolution of the individuals. We analyzed the levels of our pyramid step by step, their characteristics, and the course of their development to conquer the upper levels, transcendence, and emotional unity, as well as pointing out the significance of EI in our life.

Most of the emotional intelligence abilities and skills that are layered in the pyramid model have their origins in the three distinct and basic categories of models (Ability model, Mixed models, Trait model). Some more abilities, skills were added to be prioritized according to their contribution to the best stratification of all levels. If we were allowed an approach to the concept of emotional intelligence from our perspective, it would be the followed: "Emotional intelligence is a set of abilities and skills that a person must train and develop gradually and hierarchically to reach emotional selfrealization. It is the response to emotional stimuli, the recognition-expression of emotions, the full awareness and management of our own emotions but also the emotions of others, the social skills for better intrapersonal, interpersonal and working relationships, the empathy and compassion, the accurate discrimination of emotions with the ultimate aim of the emotional development of our potential, self-actualization, transcendence and finally the unity of emotions because humans are part of a united world". The development of emotional intelligence is not a static process, but a continuous effort to evolve to reach higher levels for better balance with ourselves and those around us, better mental and physical health, and more success. In summary, the nine stages of the pyramid of emotional intelligence are the following [27]:

Emotional stimuli: The emotional stimuli constitute the base of the pyramid where people can classify each emotional stimulus with accuracy to rapidly assess the emotional situation, to produce emotional changes [28] and connected to conscious awareness, even if it is an early stage [29,30].

Emotion Recognition, Perception-Expression of Emotions: The expression of emotions is a daily [31] and desirable condition for our own emotional state, but also for the emotional state of others. Furthermore, the ability to perceive and recognize emotions, verbally or not verbally, is critical, with research showing that vital information can be inferred from facial expressions [32-34].

Self-Awareness: The third level of the model of EI, the self-awareness one, is a holistic approach to ourselves for better development at all levels, social, professional, $[35,36]$ interpersonal, intrapersonal. It is a psychological state in which oneself becomes the focus of attention.

Self-Management: In the level of self-management, the more you learn to manage your emotions and have self-control, the greater your ability will be to articulate them in a productive way [37]. Mischel et al., (2014) refer to emotional self-management as an intrapsychic process and an attempt to inhibit impulsive emotional reactions to achieve future goals [38].

Social-Awareness, Empathy, Discrimination of Emotions: Social awareness refers to the awareness of others' emotions, needs, and concerns [18]. Moreover, with empathy, one can understand the feelings and thoughts of others taking their perspective [39]. Discrimination of emotions is also an ability to discriminate with accuracy and in detail between different emotions, to label them appropriately, to select among various emotionally charged situations for better choices and decisions [40]. 
Social Skills, Expertise in Emotions: Social skills are a prerequisite for socialization, and individualization, because these skills help gaining more knowledge about ourselves and others, which contributes to better social interactions and to the configuration of self-concept [41] Expertise in emotions could be characterized as the ability to increase sensitivity to emotional parameters and strategically expose one's own emotions and respond to emotions stemming from others [42].

Universality of Emotions, Self-Actualization: Self-Actualization is to realize and achieve your potential capacities [43], and to reach self-fulfillment in the most creative and effective way. Various authors have defined self-actualization as a life-long process [44], a way of living [45] and a challenge [46]. Self-actualization leads to the universality of emotions by understanding the difference of emotions and their meanings in other cultures too even though sometimes emotions are culturally dependent [47].

Transcendence: In the level of Transcendence, one helps others to self-actualize, find self-fulfillment, and realize their potential $[48,49]$. Stellar et al. (2017) propose a taxonomy of self-transcendent positive emotions which are classified into three broader branches: the emotion of awe and relevant emotions of moral elevation, inspiration, and admiration; compassion and related emotions of sympathy, love, and pity; and gratitude and the related emotion of appreciation [50].

Emotional Unity: Emotional unity is the final level in the pyramid of emotional intelligence. Emotions have an outstanding place in our lives because they influence them, they make changes, they formulate situations [51]. The most important thing is to perceive that we are all interconnected with other people, with the nature and the whole planet. Researchers of emotions are explaining the unity or oneness of emotion [52].

\section{$3 \quad$ Materials and Methods}

In this present study, the Nine Layer Pyramid Model Questionnaire of Emotional Intelligence was constructed to measure emotional intelligence and assess the possession of each level of the pyramid model through self-report. The questionnaire was based on the model of the emotional intelligence pyramid and all the questions are related to the nine levels. It was designed taking account of existing abilities and skills through known models of EI with detailed examination of them (Ability model, BarOn model, Goleman model, Trait model) and with the addition of some more competencies.

The Nine Layer Pyramid Model Questionnaire of Emotional Intelligence was developed for adults. Specifically, in the research it was granted to teachers of primary and secondary education to detect their overall emotional intelligence, and in which of the nine levels of the pyramid model a bigger or smaller percentage is observed. The educational field was chosen so that there is uniformity in the sample and because it is important for teachers to have emotional intelligence since they are surrounded by pure child souls. Access to the questionnaire was anonymous to encourage honest responses and none of the questions identified the respondents in any way.

Aim of the research: This study aims to quantify the emotional intelligence and investigate its dependency with the demographic characteristics of the participants. The 
goal was to develop a valid and reliable instrument tapping multidimensional construct of EI.

Research hypotheses: For the inferential part of the analysis, the following six hypotheses were tested:

1. Gender plays an important role in the levels of Emotional Intelligence.

2. Years of experience as a teacher are correlated positively with Emotional Intelligence.

3. Age is correlated positively with Emotional Intelligence.

4. There are no significant differences on Emotional intelligence based on educational level or training in special needs education.

5. There are no significant differences on Emotional intelligence based on the school grade the teachers are responsible for.

6. Special Education Relevance has an important role in the levels of Emotional Intelligence.

Research tool: The research tool (Nine Layer Pyramid Model Questionnaire of Emotional Intelligence) is consisted of 81 questions measuring different layers of Emotional Intelligence pyramid model. Answers were given on a 5-point Likert scale (1Totally Disagree, 2- Disagree, 3-Neutral, 4-Agree, 5-Totally Agree) with higher average values representing higher emotional intelligence. The questionnaire was divided in 9 dimensions ( 9 questions each) each representing an Emotional intelligence layer. Cronbach's Alpha were acceptable for all subscales except for Emotional Recognition where the results were borderline. The Cronbach's Alpha for the 9 subscales is presented below in Table 1.

Table 1. Cronbach's Alpha for Emotional Intelligence subscales

\begin{tabular}{|l|c|c|}
\hline \multicolumn{1}{|c|}{ Score } & Cronbach's Alpha & N of Items \\
\hline Emotional Stimuli & 0.788 & 9 \\
\hline Emotion Recognition & 0.637 & 9 \\
\hline Self-Awareness & 0.776 & 9 \\
\hline Self-Management & 0.700 & 9 \\
\hline Social-Awareness & 0.853 & 9 \\
\hline Social Skills & 0.835 & 9 \\
\hline Universality of Emotions & 0.876 & 9 \\
\hline Transcendence & 0.859 & 9 \\
\hline Emotional Unity & 0.885 & 9 \\
\hline Emotional Intelligence & 0.961 & 81 \\
\hline
\end{tabular}

Sample: Sample demographics are presented in Table 2. The sample consists of 520 participants, 129 males (24.8\%) and 391 females (75.2\%). Most of the respondents were between 45 and 54 years old (43.5\%) and between 34 and 44 years old $(20.6 \%)$. Regarding education most participants had a master's degree $(48.3 \%)$, followed by those with a Bachelor's degree (47.1\%) and a minority with $\mathrm{PhD}$ titles $(4.6 \%)$. Furthermore, participants were mainly elementary school teachers (46.2\%). Regarding working experience, $41.3 \%$ were working for longer than 20 years in education. A total of 107 (20.6\%) participants had degrees which are relevant with special needs education, with most of those degrees being Master's degrees (70.1\%). 
Table 2. Sample Demographics $(\mathrm{N}=520)$

\begin{tabular}{|c|c|c|}
\hline Questions & $\mathbf{N}$ & Percentages \\
\hline \multicolumn{3}{|l|}{ Gender } \\
\hline Male & 129 & $24.8 \%$ \\
\hline Female & 391 & $75.2 \%$ \\
\hline \multicolumn{3}{|l|}{ Age } \\
\hline $25-34$ & 86 & $16.5 \%$ \\
\hline $35-44$ & 107 & $20.6 \%$ \\
\hline $45-54$ & 226 & $43.5 \%$ \\
\hline Over 55 years & 101 & $19.4 \%$ \\
\hline \multicolumn{3}{|l|}{ Educational Level } \\
\hline University Degree & 245 & $47.1 \%$ \\
\hline Master's Degree & 251 & $48.3 \%$ \\
\hline PhD Title & 24 & $4.6 \%$ \\
\hline \multicolumn{3}{|l|}{ School Grade } \\
\hline Primary (kindergarten) & 81 & $15.6 \%$ \\
\hline Primary (elementary) & 240 & $46.2 \%$ \\
\hline Secondary & 199 & $38.3 \%$ \\
\hline \multicolumn{3}{|l|}{ Years of working experience } \\
\hline $1-10$ & 107 & $20.6 \%$ \\
\hline $11-20$ & 198 & $38.1 \%$ \\
\hline $20+$ & 215 & $41.3 \%$ \\
\hline \multicolumn{3}{|l|}{ Special Education Relevance } \\
\hline No & 413 & $79.4 \%$ \\
\hline Yes & 107 & $20.6 \%$ \\
\hline \multicolumn{3}{|l|}{ If yes, which degrees are Relevant } \\
\hline Bachelor's Degree & 27 & $25.2 \%$ \\
\hline Master's Degree & 75 & $70.1 \%$ \\
\hline Both Bachelor's Degree and Master's Degree & 4 & $3.7 \%$ \\
\hline PhD Title & \multicolumn{2}{|r|}{$0.9 \%$} \\
\hline
\end{tabular}

Statistical methods: To investigate the six hypotheses of this study, a series of inductive tests were applied to the date. More specifically, for the $1^{\text {st }}, 4^{\text {th }}, 5^{\text {th }}$ and $6^{\text {th }}$ hypothesis, the parametric T-tests and one-way ANOVA were conducted. The choice of tests was based on Central limit theorem in regard to the sufficiently large sample size. T-tests were used where the grouping factor was dichotomous and one-way ANOVA when it had 3 or more values. For the $2^{\text {nd }}$ and $3^{\text {rd }}$ hypothesis the Pearson's Correlation coefficient test was conducted since age and years of experience were ordinal. The Pearson correlation coefficient measures linear relationships between variables.

\section{$4 \quad$ Results}

Emotional Intelligence Scale: In order to present the emotional intelligence scale, a total of 10 new variables were created by averaging the questions in each dimension. Additionally, a discrete score measuring the entire Emotional Intelligence scale deriving from all 81 questions. Some of the statements were reverse coded where it was appropriate, to create interpretable scores. Table 3 presents the means, standard deviations, as well as the Cronbach's Alpha for each dimension. The highest scores on 
average were reported for Universality of Emotions $(\mathrm{M}=4.34)$, while the lowest were reported for Self-Management $(\mathrm{M}=3.55)$. There were no missing data as the structure of the questionnaire did not allow submission without full completion.

Table 3. Means, standard deviations and Cronbach's Alpha for EI scales and subscales

\begin{tabular}{|l|c|c|c|c|}
\hline & Mean & Std. Deviation & N of Questions & Cronbach's Alpha \\
\hline Emotional Stimuli & 4.05 & 0.491 & 9 & 0.788 \\
\hline Emotion Recognition & 3.99 & 0.397 & 9 & 0.637 \\
\hline Self-Awareness & 4.01 & 0.484 & 9 & 0.776 \\
\hline Self-Management & 3.55 & 0.513 & 9 & 0.700 \\
\hline Social-Awareness & 4.15 & 0.486 & 9 & 0.853 \\
\hline Social Skills & 4.00 & 0.491 & 9 & 0.835 \\
\hline Universality of Emotions & 4.34 & 0.506 & 9 & 0.876 \\
\hline Transcendence & 4.16 & 0.547 & 9 & 0.859 \\
\hline Emotional Unity & 4.17 & 0.578 & 9 & 0.885 \\
\hline Emotional Intelligence & $\mathbf{4 . 0 5}$ & $\mathbf{0 . 3 9 3}$ & $\mathbf{8 1}$ & $\mathbf{0 . 9 6 1}$ \\
\hline
\end{tabular}

It was subsequently tested whether the first and second highest scores for each group of school grade were similar. For teachers of kindergarten Universality of emotions and Social-Awareness were the 2 highest dimensions, while for elementary teachers as well as teachers of secondary education, Universality of emotions and Emotional Unity were the two highest layers of EI.

1st Hypothesis: A total of $10 \mathrm{~T}$-tests were conducted that revealed 5 statistically significant results. The detailed T-test results and mean differences are presented in Table 4. Test results showed a significant effect of gender was upon Emotional Stimuli $(\mathrm{t}(518)=-3.217, \mathrm{p}=0.001)$, upon Emotional Recognition $(\mathrm{t}(518)=-3.786, \mathrm{p}<0.001)$ upon Universality of Emotions $(\mathrm{t}(518)=-2.086, \mathrm{p}=0.038)$, upon Transcendence $(\mathrm{t}(518)=-2.017, \mathrm{p}=0.044)$ and upon the totality of Emotional Intelligence $(\mathrm{t}(518)=$ $1.996, \mathrm{p}=0.047)$. For all the significant differences, female teachers always reported higher scores compared to males.

Table 4. P-values and mean differences of EI between male and female teachers

\begin{tabular}{|l|c|c|c|}
\hline \multicolumn{1}{|c|}{ Mean differences } & Males & Females & P-value (Gender) \\
\hline Emotional Stimuli & 3.93 & 4.09 & 0.001 \\
\hline Emotion Recognition & 3.88 & 4.03 & 0.000 \\
\hline Self-Awareness & 3.96 & 4.02 & 0.170 \\
\hline Self-Management & 3.62 & 3.53 & 0.086 \\
\hline Social-Awareness & 4.09 & 4.18 & 0.086 \\
\hline Social Skills & 3.96 & 4.02 & 0.226 \\
\hline Universality of Emotions & 4.26 & 4.37 & 0.038 \\
\hline Transcendence & 4.05 & 4.19 & 0.044 \\
\hline Emotional Unity & 4.13 & 4.19 & 0.278 \\
\hline Emotional Intelligence & $\mathbf{3 . 9 9}$ & $\mathbf{4 . 0 7}$ & $\mathbf{0 . 0 4 7}$ \\
\hline
\end{tabular}


2nd and 3rd Hypothesis: To answer the $2^{\text {nd }}$ and $3^{\text {rd }}$ hypothesis, the Pearson correlation coefficient test was used (see Table 5). A total of 20 tests, revealed 5 statistically significant correlations. Age had Significant correlations with Self-Awareness $(r=$ $+0.152, \mathrm{p}<0.001)$ with Self-Management $(\mathrm{r}=0.107, \mathrm{p}=0.014)$ and with the total of Emotional Intelligence $(r=0.092, p=0.036)$. The correlations' intensity is considered "weak" and were all positive, indicating that as age increases, so does Emotional intelligence. Furthermore, the years of teaching experience had significant correlations with Self-Awareness $(r=0.142, p=0.001)$ and Self-Management (Pearson, $r=0.132, p=$ 0.002). The intensity is again considered "weak"and all correlations were all positive, indicating that more experience teachers tend to have higher Emotional intelligence.

Table 5. Pearson correlation coefficients for EI, Age and Years of teaching $(\mathrm{N}=520)$

\begin{tabular}{|l|c|c|}
\hline \multicolumn{1}{|c|}{ Pearson Correlation Coefficients } & Age & Years of teaching \\
\hline Emotional Stimuli & 0.056 & 0.039 \\
\hline Emotion Recognition & 0.065 & 0.053 \\
\hline Self-Awareness & $0.152^{* *}$ & $0.142^{* *}$ \\
\hline Self-Management & $0,107^{*}$ & $0.132^{* *}$ \\
\hline Social-Awareness & 0.027 & 0.013 \\
\hline Social Skills & 0.078 & 0.054 \\
\hline Universality of Emotions & 0.053 & 0.028 \\
\hline Transcendence & 0.057 & 0.066 \\
\hline Emotional Unity & 0.059 & 0.069 \\
\hline Emotional Intelligence & $0.092^{*}$ & 0.085 \\
\hline
\end{tabular}

4th Hypothesis: A total of 10 t-tests were performed for differences on EI between teachers with special needs degree relevance, and those without. Results revealed 4 significant differences (see Table 6). Results showed a significant effect upon Special needs degree relevance upon Emotional Stimuli $(\mathrm{T}$-test, $\mathrm{t}(518)=2.343, \mathrm{p}=0.020)$, upon Emotional Recognition (T-test, $\mathrm{t}(518)=3.091, \mathrm{p}=0.002$ ) upon Self-Awareness (T-test, $\mathrm{t}(518)=2.389, \mathrm{p}=0.017)$ and upon the total Emotional Intelligence (T-test, $\mathrm{t}(145)=2.164, \mathrm{p}=0.032$ ). In all cases, teachers with training in Special needs education reported higher EI scores.

Table 6. P-values and mean differences of EI based on Special Education Relevance

\begin{tabular}{|l|c|c|c|}
\hline \multicolumn{1}{|c|}{ Mean differences } & Degree with Relevance & No Relevance & $\begin{array}{c}\text { P-value (Special Education } \\
\text { Relevance) }\end{array}$ \\
\hline Emotional Stimuli & 4.15 & 4.02 & 0.020 \\
\hline Emotion Recognition & 4.10 & 3.97 & 0.002 \\
\hline Self-Awareness & 4.11 & 3.98 & 0.017 \\
\hline Self-Management & 3.65 & 3.52 & 0.051 \\
\hline Social-Awareness & 4.23 & 4.14 & 0.089 \\
\hline Social Skills & 4.05 & 3.99 & 0.287 \\
\hline Universality of Emotions & 4.41 & 4.33 & 0.187 \\
\hline Transcendence & 4.24 & 4.14 & 0.136 \\
\hline Emotional Unity & 4.25 & 4.15 & 0.135 \\
\hline Emotional Intelligence & 4.13 & 4.03 & 0.032 \\
\hline
\end{tabular}


Additionally, a total of 10 one-way ANOVA tests were performed for differences on Emotional Intelligence between the different educational levels of teachers (Table 7). The results revealed 7 significant differences. There was a significant effect of Educational level upon Emotional Stimuli $(\mathrm{F}(2,517)=3.242, \mathrm{p}=0.040)$, Self-Awareness $(F(2,517)=4.639, p=0.010)$, Self-Management $(F(2,517)=5.44, p=0.005)$. Social Skills $(\mathrm{F}(2,517)=4.483, \mathrm{p}=0.012)$. Transcendence $(\mathrm{F}(2,517)=3.778, \mathrm{p}=0.024)$. Emotional Unity $(\mathrm{F}(2,517)=4.078, \mathrm{p}=0.017)$ and total Emotional Intelligence $(\mathrm{F}(2,517)=5.518, \mathrm{p}=0.004)$. For all significant results, participants with $\mathrm{PhD}$ reported the highest Emotional intelligence levels, followed by those with a Master's Degree and lastly those with a Bachelor's degree that had the lowest scores, indicating that EI is higher in people with higher educational levels.

Table 7. P-values and mean differences of EI based on Educational Level

\begin{tabular}{|l|c|c|c|c|}
\hline \multicolumn{1}{|c|}{ Mean differences } & Bachelor's & Master's & PhD & P-value (Educational Level) \\
\hline Emotional Stimuli & 3.99 & 4.09 & 4.17 & 0.040 \\
\hline Emotional Recognition & 3.95 & 4.04 & 3.96 & 0.053 \\
\hline Self-Awareness & 3.94 & 4.06 & 4.12 & 0.010 \\
\hline Self-Management & 3.47 & 3.61 & 3.66 & 0.005 \\
\hline Social-Awareness & 4.11 & 4.18 & 4.25 & 0.178 \\
\hline Social Skills & 3.94 & 4.04 & 4.20 & 0.012 \\
\hline Universality of Emotions & 4.29 & 4.38 & 4.46 & 0.092 \\
\hline Transcendence & 4.09 & 4.22 & 4.25 & 0.024 \\
\hline Emotional Unity & 4.10 & 4.23 & 4.31 & 0.017 \\
\hline Emotional Intelligence & 3.99 & 4.09 & 4.15 & 0.004 \\
\hline
\end{tabular}

5th Hypothesis: To investigate the differences on Emotional Intelligence between the different school grades the teachers are responsible for, once again 10 one-way ANOVA tests were performed (Table 8 ). The results revealed only 1 statistically significant difference, as for the Emotional Recognition $(\mathrm{F}(2,517)=4.438, \mathrm{p}=0.012)$. Kindergarten teachers appear to have a higher score of Emotional Recognition, followed by the elementary teachers, while the secondary teachers had the lowest score.

Table 8. P-values and mean differences of EI based on School Grade

\begin{tabular}{|l|c|c|c|c|}
\hline \multicolumn{1}{|c|}{ Mean differences } & $\begin{array}{c}\text { Primary (kinder- } \\
\text { garten) }\end{array}$ & $\begin{array}{c}\text { Primary (ele- } \\
\text { mentary) }\end{array}$ & Secondary & P-value (School Grade) \\
\hline Emotional Stimuli & 4.15 & 4.03 & 4.03 & 0.138 \\
\hline Emotional Recognition & 4.08 & 4.01 & 3.94 & 0.012 \\
\hline Self-Awareness & 4.08 & 3.98 & 4.01 & 0.255 \\
\hline Self-Management & 3.57 & 3.55 & 3.54 & 0.947 \\
\hline Social-Awareness & 4.24 & 4.12 & 4.16 & 0.171 \\
\hline Social Skills & 4.09 & 3.97 & 4.00 & 0.148 \\
\hline Universality of Emotions & 4.34 & 4.30 & 4.40 & 0.124 \\
\hline Transcendence & 4.22 & 4.13 & 4.17 & 0.470 \\
\hline Emotional Unity & 4.20 & 4.13 & 4.21 & 0.345 \\
\hline Emotional Intelligence & 4.11 & 4.02 & 4.05 & 0.253 \\
\hline
\end{tabular}


6th Hypothesis: Once again, a total of 10 T-tests were conducted that revealed 4 statistically significant results, as presented in Table 9. Test results showed a significant effect of Special Education Relevance upon Emotional Stimuli (T-test, $\mathrm{t}=518, \mathrm{p}=$ 0.020), Emotional Recognition (T-test, $\mathrm{t}=518, \mathrm{p}=0.002$ ), Self-Awareness (T-test, $\mathrm{t}=$ $518, \mathrm{p}=0.017)$, and upon the totality of Emotional Intelligence (T-test, $\mathrm{t}=145, \mathrm{p}=$ 0.032). For all the significant differences, teachers with a special education relevance seem to have a higher mean, hence a higher score.

Table 9. P-values and mean differences of EI based on Special Education Relevance

\begin{tabular}{|l|c|c|c|}
\hline \multicolumn{1}{|c|}{ Mean differences } & No & Yes & P-value (Special Education Relevance) \\
\hline Emotional Stimuli & 4.02 & 4.15 & 0.020 \\
\hline Emotional Recognition & 3.97 & 4.10 & 0.002 \\
\hline Self-Awareness & 3.98 & 4.11 & 0.017 \\
\hline Self-Management & 3.52 & 3.65 & 0.051 \\
\hline Social-Awareness & 4.14 & 4.23 & 0.089 \\
\hline Social Skills & 3.99 & 4.05 & 0.287 \\
\hline Universality of Emotions & 4.33 & 4.41 & 0.187 \\
\hline Transcendence & 4.14 & 4.24 & 0.136 \\
\hline Emotional Unity & 4.15 & 4.25 & 0.135 \\
\hline Emotional Intelligence & 4.03 & 4.13 & 0.032 \\
\hline
\end{tabular}

Additionally, in Table 10 the linear correlations among the 9 scales of emotional intelligence are presented. The results were statistically significant in every test in $99 \%$ trust level (all p-values $<0.001$ ), indicating positive correlation in all tested pairs. Concluding, as one of the scales increased, so do all the others, with the most intense dependency, being between universality and transcendence.

Table 10. Pearson's Correlation between the 9 scales of Emotional Intelligence

\begin{tabular}{|c|c|c|c|c|c|c|c|c|c|}
\hline & $\begin{array}{c}\text { Emo- } \\
\text { tional } \\
\text { Stimuli }\end{array}$ & $\begin{array}{c}\text { Emo- } \\
\text { tional } \\
\text { Recog- } \\
\text { nition }\end{array}$ & $\begin{array}{c}\text { Self- } \\
\text { Aware- } \\
\text { ness }\end{array}$ & $\begin{array}{c}\text { Self-Man- } \\
\text { agement }\end{array}$ & $\begin{array}{c}\text { Social- } \\
\text { Awareness }\end{array}$ & $\begin{array}{l}\text { Social } \\
\text { Skills }\end{array}$ & $\begin{array}{l}\text { Univer- } \\
\text { sality of } \\
\text { Emotions }\end{array}$ & $\begin{array}{c}\text { Tran- } \\
\text { scend- } \\
\text { ence }\end{array}$ & $\begin{array}{l}\text { Emo- } \\
\text { tional } \\
\text { Unity }\end{array}$ \\
\hline \multirow{3}{*}{$\begin{array}{l}\text { Emotional } \\
\text { Stimuli }\end{array}$} & 1 &, $557^{* *}$ &, $577^{* *}$ &, $298^{* *}$ &, $524^{* *}$ &, $469^{* *}$ &, $458^{* *}$ &, $412^{* *}$ &, $402^{* *}$ \\
\hline & & 0,000 & 0,000 & 0,000 & 0,000 & 0,000 & 0,000 & 0,000 & 0,000 \\
\hline & 520 & 520 & 520 & 520 & 520 & 520 & 520 & 520 & 520 \\
\hline \multirow{3}{*}{$\begin{array}{l}\text { Emotional } \\
\text { Recogni- } \\
\text { tion }\end{array}$} &, $557^{* *}$ & 1 &, $560^{* *}$ &, $353^{* *}$ &, $597^{* *}$ &, $542^{* *}$ &, $492^{* *}$ &, $549^{* * *}$ &, $487^{* *}$ \\
\hline & 0,000 & & 0,000 & 0,000 & 0,000 & 0,000 & 0,000 & 0,000 & 0,000 \\
\hline & 520 & 520 & 520 & 520 & 520 & 520 & 520 & 520 & 520 \\
\hline $\begin{array}{l}\text { Self- } \\
\text { Awareness }\end{array}$ &, $577^{* *}$ &, $560^{* *}$ & 1 &, $538^{* *}$ &, $561^{* *}$ &, $598^{* *}$ &, $585^{* *}$ &, $558^{* *}$ &, $532^{* *}$ \\
\hline
\end{tabular}


Paper-Nine Layer Pyramid Model Questionnaire for Emotional Intelligence

\begin{tabular}{|c|c|c|c|c|c|c|c|c|c|}
\hline & 0,000 & 0,000 & & 0,000 & 0,000 & 0,000 & 0,000 & 0,000 & 0,000 \\
\hline & 520 & 520 & 520 & 520 & 520 & 520 & 520 & 520 & 520 \\
\hline \multirow{3}{*}{$\begin{array}{l}\text { Self-Man- } \\
\text { agement }\end{array}$} &, $298^{* *}$ &, $353^{* *}$ &, $538^{* *}$ & 1 &, $440^{* *}$ &, $547^{* *}$ &, $522^{* *}$ &, $505^{* *}$ &, $506^{* *}$ \\
\hline & 0,000 & 0,000 & 0,000 & & 0,000 & 0,000 & 0,000 & 0,000 & 0,000 \\
\hline & 520 & 520 & 520 & 520 & 520 & 520 & 520 & 520 & 520 \\
\hline \multirow{3}{*}{$\begin{array}{l}\text { Social- } \\
\text { Awareness }\end{array}$} &, $524^{* *}$ &, $597^{* *}$ &, $561^{* *}$ &, $440^{* *}$ & 1 &, $701^{* *}$ & , $667^{* *}$ & ,678 &, $672^{* *}$ \\
\hline & 0,000 & 0,000 & 0,000 & 0,000 & & 0,000 & 0,000 & 0,000 & 0,000 \\
\hline & 520 & 520 & 520 & 520 & 520 & 520 & 520 & 520 & 520 \\
\hline \multirow{3}{*}{$\begin{array}{l}\text { Social } \\
\text { Skills }\end{array}$} &, $469^{* *}$ &, $542^{* *}$ &, $598^{* *}$ &, $547^{* *}$ &, $701^{* *}$ & 1 &, $712^{* *}$ &, $757^{* *}$ & ,696** \\
\hline & 0,000 & 0,000 & 0,000 & 0,000 & 0,000 & & 0,000 & 0,000 & 0,000 \\
\hline & 520 & 520 & 520 & 520 & 520 & 520 & 520 & 520 & 520 \\
\hline \multirow{3}{*}{$\begin{array}{l}\text { Universal- } \\
\text { ity of Emo- } \\
\text { tions }\end{array}$} &, $458^{* *}$ &, $492^{* *}$ &, $585^{* *}$ &, $522^{* *}$ &, $667^{* *}$ &, $712^{* *}$ & 1 &, $811^{* *}$ &, $766^{* *}$ \\
\hline & 0,000 & 0,000 & 0,000 & 0,000 & 0,000 & 0,000 & & 0,000 & 0,000 \\
\hline & 520 & 520 & 520 & 520 & 520 & 520 & 520 & 520 & 520 \\
\hline \multirow{3}{*}{$\begin{array}{l}\text { Transcend- } \\
\text { ence }\end{array}$} &, $412^{* *}$ &, $549^{* *}$ &, $558^{* *}$ &, $505^{* *}$ &, $678^{* *}$ &, $757^{* *}$ &, $811^{* *}$ & 1 &, $802^{* *}$ \\
\hline & 0,000 & 0,000 & 0,000 & 0,000 & 0,000 & 0,000 & 0,000 & & 0,000 \\
\hline & 520 & 520 & 520 & 520 & 520 & 520 & 520 & 520 & 520 \\
\hline \multirow{3}{*}{$\begin{array}{l}\text { Emotional } \\
\text { Unity }\end{array}$} &, $402^{* *}$ &, $487^{* *}$ &, $532^{* *}$ &, $506^{* *}$ &, $672^{* *}$ &, $696^{* *}$ &, $766^{* *}$ &, $802^{* *}$ & 1 \\
\hline & 0,000 & 0,000 & 0,000 & 0,000 & 0,000 & 0,000 & 0,000 & 0,000 & \\
\hline & 520 & 520 & 520 & 520 & 520 & 520 & 520 & 520 & 520 \\
\hline
\end{tabular}

Continuing, a factor analysis using varimax rotation was conducted, to extract the factor loadings of the questionnaire. The loadings of each variable are presented below in Table 11. 
Table 11. Factor loadings

\begin{tabular}{|c|c|c|}
\hline Factor & Questions/Items & $\begin{array}{c}\text { Factor } \\
\text { loadings }\end{array}$ \\
\hline \multirow{21}{*}{$1 \mathrm{st}$} & $\begin{array}{l}\text { 64. I am interested in my fellow man, his needs, and his emotional and social de- } \\
\text { velopment. }\end{array}$ & 0,736 \\
\hline & 62. I have feelings of love, affection, and compassion for my fellow man. & 0,729 \\
\hline & 44. I'm sensitive to other people 's emotional state. & 0,685 \\
\hline & $\begin{array}{l}\text { 63. I cultivate and develop positive emotions so that they are universally addressed } \\
\text { to everyone and everything, respecting that every creature, every social group, } \\
\text { every civilization has its own values, emotional expressions, and reactions. }\end{array}$ & 0,677 \\
\hline & 38. I care about other people's emotions and concerns. & 0,675 \\
\hline & $\begin{array}{l}\text { 40. I recognize and respect the individual / social differences and the uniqueness of } \\
\text { human being. }\end{array}$ & 0,661 \\
\hline & $\begin{array}{l}\text { 78. I feel the life situation of another person regardless of the social group and the } \\
\text { nationality to which he belongs. }\end{array}$ & 0,647 \\
\hline & $\begin{array}{l}\text { 76. I feel inner harmony and mental uplift when I do positive actions towards the } \\
\text { social and natural environment. }\end{array}$ & 0,588 \\
\hline & 67. I reward the efforts and successes of other people. & 0,550 \\
\hline & $\begin{array}{l}\text { 42. I understand the values and culture of a team and I can collaborate and under- } \\
\text { stand people from different social backgrounds and civilization. }\end{array}$ & 0,543 \\
\hline & $\begin{array}{l}\text { 79. I am an entity that belongs to a more general whole and I do not do things that } \\
\text { can harm others or the planet in general. }\end{array}$ & 0,521 \\
\hline & 41. I can put myself in someone else's shoes, understand him and feel him. & 0,519 \\
\hline & 60. I have a strong sense of worth, gratitude and truth in my life. & 0,517 \\
\hline & $\begin{array}{l}\text { 66. I help others better manage negative emotional states e.g., stress, irritability, } \\
\text { anger. }\end{array}$ & 0,488 \\
\hline & 54. I believe that good, interpersonal, emotional relationships are important. & 0,474 \\
\hline & 72. I admit my mistakes and try to do the right thing. & 0,460 \\
\hline & 73. I believe that the existence of emotions gives meaning to life. & 0,458 \\
\hline & $\begin{array}{l}\text { 43. I listen carefully and actively to the person who wants to talk to me about a } \\
\text { topic that concerns him. }\end{array}$ & 0,458 \\
\hline & $\begin{array}{l}\text { 46. I try to provide support, encouragement, inspiration and create a positive emo- } \\
\text { tional climate in my personal and working life. }\end{array}$ & 0,439 \\
\hline & $\begin{array}{l}\text { 47. I can solve personal and interpersonal problems by considering the emotions } \\
\text { and perspective of other people. }\end{array}$ & 0,405 \\
\hline & $\begin{array}{l}\text { 39. I am aware of the emotions and thoughts of the people around me and I try to } \\
\text { meet their needs. }\end{array}$ & 0,399 \\
\hline \multirow{9}{*}{ 2nd } & 69. I enjoy life and I am optimistic. & 0,752 \\
\hline & $\begin{array}{l}\text { 70. I am possessed by higher feelings of euphoria, joy, and awe, which I try to con- } \\
\text { vey to others. }\end{array}$ & 0,681 \\
\hline & $\begin{array}{l}\text { 61. I appreciate the life and goods it offers me, and I have positive feelings even } \\
\text { for simple everyday things. }\end{array}$ & 0,620 \\
\hline & $\begin{array}{l}\text { 80. I love myself and I try to channel this feeling into everything around me (peo- } \\
\text { ple, animals, plants, etc.). }\end{array}$ & 0,617 \\
\hline & $\begin{array}{l}\text { 59. I focus on my positive emotions to activate me, to motivate me, to expand my } \\
\text { thought and be a guide for changes I must make in my life. }\end{array}$ & 0,603 \\
\hline & 75. I am in emotional harmony with nature and the universe. & 0,554 \\
\hline & 74. I base my decisions on my positive emotions. & 0,546 \\
\hline & 68. I engage in activities that create emotional fullness for me. & 0,542 \\
\hline & $\begin{array}{l}\text { 56. I feel positive emotions (e.g., peace, joy) and I am good with myself even when } \\
\text { I am alone. }\end{array}$ & 0,538 \\
\hline
\end{tabular}




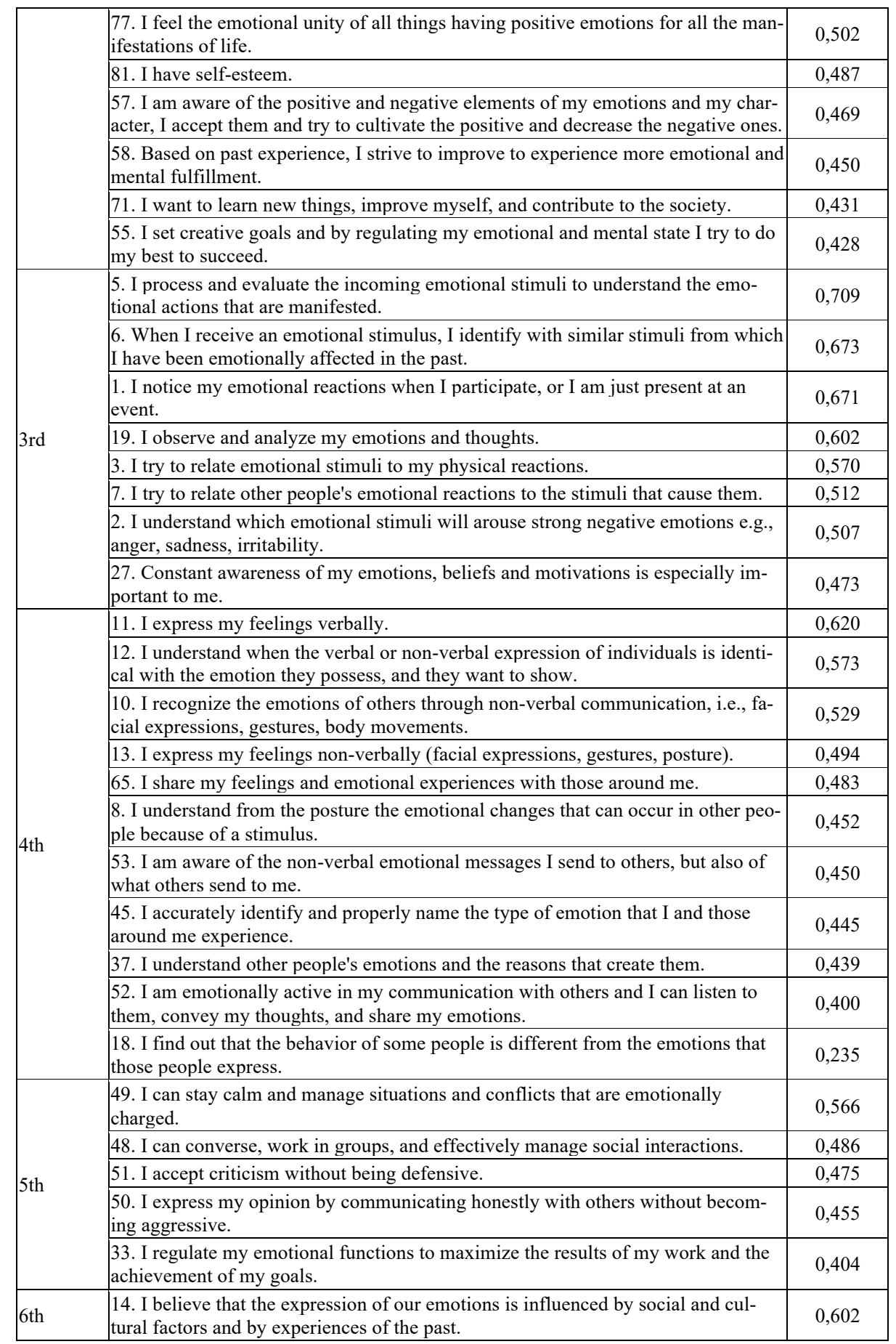




\begin{tabular}{|c|c|c|}
\hline & $\begin{array}{l}\text { 16. I believe that recognizing emotions is an important skill that guides our choices } \\
\text { and actions. }\end{array}$ & 0,578 \\
\hline & $\begin{array}{l}\text { 15. I believe that the expression of our emotions is necessary and plays an im- } \\
\text { portant role in everyday interaction and in interpersonal relationships. }\end{array}$ & 0,500 \\
\hline & 9. I believe that emotional stimuli motivate a person and regulate his behavior. & 0,455 \\
\hline \multirow{6}{*}{ 7th } & 34. Even small problems can cause me intense emotional turmoil. & 0,740 \\
\hline & 36. I need the help of others to manage my emotional tensions. & 0,662 \\
\hline & 17. I draw hasty conclusions about the emotions that other people may have. & 0,609 \\
\hline & $\begin{array}{l}\text { 30. When there are strong negative emotions (e.g., anxiety, anger), my mental } \\
\text { function becomes difficult. }\end{array}$ & 0,567 \\
\hline & 26. Sometimes I feel confused by the emotions I feel inside. & 0,554 \\
\hline & $\begin{array}{l}\text { 4. Some emotional stimuli can cause me strong emotional reactions (positive and / } \\
\text { or negative). }\end{array}$ & $-0,318$ \\
\hline \multirow{4}{*}{8 th } & $\begin{array}{l}\text { 29. Evaluating the priority of social contacts and relationships I do not express un- } \\
\text { pleasant feelings not to bother/hurt others. }\end{array}$ & 0,670 \\
\hline & $\begin{array}{l}\text { 28. I observe my emotions when they arise, and I can keep the positive emotions } \\
\text { and calm the negative ones. }\end{array}$ & 0,600 \\
\hline & $\begin{array}{l}\text { 32. I pay attention to the manifestation of my emotions and regulate them to opti- } \\
\text { mize my behavior. }\end{array}$ & 0,498 \\
\hline & $\begin{array}{l}\text { 35. I manage my emotional functions properly so not to be emotional upset from } \\
\text { negative impacts from my social environment. }\end{array}$ & 0,443 \\
\hline \multirow{7}{*}{9 th } & $\begin{array}{l}\text { 22. I understand when I am possessed by positive emotions (joy, enthusiasm) and } \\
\text { when I am possessed by negative ones (sadness, irritation). }\end{array}$ & 0,658 \\
\hline & $\begin{array}{l}\text { 21. I am fully aware of my emotions, my character, and my behavior as well as } \\
\text { their impact to other people. }\end{array}$ & 0,544 \\
\hline & $\begin{array}{l}\text { 23. I have confidence as a person and I know what motivates me, what satisfies me } \\
\text { and what I can achieve. }\end{array}$ & 0,478 \\
\hline & $\begin{array}{l}\text { 20. I can describe my emotional state at any time and locate the source of my emo- } \\
\text { tions. }\end{array}$ & 0,454 \\
\hline & 24. I recognize and evaluate my strengths and weaknesses in the emotional field. & 0,414 \\
\hline & 31. I take responsibility for my emotional behaviors and their effects. & 0,391 \\
\hline & $\begin{array}{l}\text { 25. When I do something in my work and / or in my daily life, I always try to com- } \\
\text { plete it. }\end{array}$ & 0,352 \\
\hline \multicolumn{3}{|c|}{ Extraction Method: Principal Component Analysis. Rotation Method: Varimax with Kaiser Normalization } \\
\hline & & \\
\hline
\end{tabular}

The first level of the emotional intelligence pyramid, emotional stimuli, includes the questions 1-9. The second level, emotion recognition-perception-expression of emotions, includes the questions 10-18. The questions 19-27 belongs to the third level of self - awareness. The self - management level includes the questions 28-36. As for the fifth level of the pyramid, social awareness-empathy-discrimination of emotions, it includes the questions 37-45. The sixth level of social skills and expertise in emotions consists of the questions 46-54. The next level of universality of emotions and selfactualization contains questions 55-63. The penultimate level of transcendence composed of questions $64-72$. The last level of the questionnaire that of emotional unity includes the questions $73-81$.

Completing the research, to ensure the reliability of the questionnaire measuring the emotional intelligence, an iterative algorithm was used. This algorithm, through a 
random sampling process, collected 1000 different subsamples from the initial dataset (520 participants), consisted of 100 participants each. Next, for every case the Cronbach's Alpha was calculated for the 9 subscales and the whole emotional intelligence scale. The results were remarkable considering that Cronbach's Alpha as an indicator is overly sensitive to the sample's size. The Table 10 below shows the minimum and maximum value of the Cronbach's index from the 1000 repetitions, while also through the means and standard deviations of the reliability values it seems that in total, the 1000 samples also had similarly high reliability as the initial sample. The consistency between each subsample's reliability can be presented as a strong indicator that the studied questionnaire measures emotional intelligence accurately and reliably.

Table 12. Cronbach's Alpha in 1000 subsamples comparing to the initial dataset

\begin{tabular}{|c|c|c|c|c|}
\hline \multirow{2}{*}{ Score } & \multirow{2}{*}{$\begin{array}{c}\text { Cronbach's Alpha (For } \\
\text { the whole sample) }\end{array}$} & \multicolumn{3}{|c|}{ Repetitive algorithm } \\
\hline & & Min Cronbach's & Max Cronbach's & Mean ( \pm std. dev.) \\
\hline Emotional Stimuli & 0.788 & 0.744 & 0.815 & $0.799 \pm 0.125$ \\
\hline $\begin{array}{l}\text { Emotional Recogni- } \\
\text { tion }\end{array}$ & 0.637 & 0.548 & 0.725 & $0.6065 \pm 0.111$ \\
\hline Self-Awareness & 0.776 & 0.723 & 0.839 & $0.771 \pm 0.120$ \\
\hline Self-Management & 0.700 & 0.658 & 0.888 & $0.823 \pm 0.088$ \\
\hline Social-Awareness & 0.853 & 0.822 & 0.926 & $0.884 \pm 0.128$ \\
\hline Social Skills & 0.835 & 0.803 & 0.924 & $0.8435 \pm 0.095$ \\
\hline $\begin{array}{l}\text { Universality of } \\
\text { Emotions }\end{array}$ & 0.876 & 0.788 & 0.978 & $0.833 \pm 0.098$ \\
\hline Transcendence & 0.859 & 0.825 & 0.849 & $0.887 \pm 0.124$ \\
\hline Emotional Unity & 0.885 & 0.858 & 0.925 & $0.891 \pm 0.058$ \\
\hline $\begin{array}{l}\text { Emotional Intelli- } \\
\text { gence }\end{array}$ & 0.961 & 0.923 & 0.988 & $0.995 \pm 0.038$ \\
\hline
\end{tabular}

\section{$5 \quad$ Discussion and Conclusion}

This study aimed to quantify the emotional intelligence and investigate its dependency with the demographic characteristics of the participants. The sample consists of 520 participants, most of them females. The majority of respondents were between 45 and 54 years old and regarding education, most of the participants had a master's degree. Furthermore, participants were mainly elementary school teachers working for longer than 20 years in education, with Master's degrees relevant to special needs education.

The inductive statistics revealed significant effect of gender upon Emotional Stimuli, Emotion Recognition, Universality of Emotions, Transcendence, and the total Emotional Intelligence, in which female teachers always reported higher scores compared to males.

Age had Significant correlations with Self-Awareness, Self-Management, and the total Emotional Intelligence, indicating that as age increases, so does Emotional intelligence. Furthermore, the years of teaching experience had significant correlations with 
Self-Awareness and Self-Management, indicating that more experience teachers tend to have higher Emotional intelligence.

As for differences on EI between teachers with special needs degree relevance, and those without, 4 significant results were revealed. More specifically, Special needs degree relevance affects significantly Emotional Stimuli, Emotion Recognition, SelfAwareness, and the total Emotional Intelligence. In all cases, teachers with training in Special needs education reported higher EI scores.

Additionally, the tests between Emotional Intelligence among the different educational levels of teachers, revealed 7 significant differences. There was a significant effect of Educational level upon Emotional Stimuli, Self-Awareness, Self-Management, Social Skills, Transcendence, Emotional Unity, and total Emotional Intelligence. For all significant results, participants with $\mathrm{PhD}$ reported the highest Emotional intelligence levels, followed by those with a Master's Degree and lastly those with a Bachelor's degree that had the lowest scores, indicating that EI is higher in people with higher educational levels.

Investigating the differences on Emotional Intelligence between the different school grades the teachers are responsible for, it was revealed that only Emotion Recognition was affected. More specifically, Kindergarten teachers appear to have a higher score of Emotional Recognition, followed by the elementary teachers, while the secondary teachers had the lowest score.

Continuing, a significant effect of Special Education Relevance upon Emotional Stimuli, Emotion Recognition, Self-Awareness, and the totality of Emotional Intelligence was revealed, with teachers with a special education relevance having a higher score.

Additionally, the 9 scales of emotional intelligence were positively correlated with each other, concluding that as one of the scales increased, so do all the others, with the most intense dependency, being between universality and transcendence.

Completing the research, to ensure the reliability of the questionnaire measuring the emotional intelligence, an iterative algorithm was used. This algorithm, through a random sampling process, collected 1000 different subsamples from the initial dataset (521 participants), consisted of 100 participants each. Next, for every case the Cronbach's Alpha was calculated for the 9 subscales and the whole emotional intelligence scale. The consistency between each subsample's reliability can be presented as a strong indicator that the studied questionnaire measures emotional intelligence accurately and reliably.

It was observed that the group of teachers possesses better some levels of emotional intelligence of the pyramid compared to some other levels which possesses them, but to a lesser extent. Overall, their level of emotional intelligence is quite good. Based on these results, various strategies can be made to develop and to improve the levels where the amount of possession is lower. Also, the demographic factors we set, seem to affect the dimensions of emotional intelligence but not all of them. The purpose of the construction of the emotional intelligence pyramid is to show the hierarchical levels of which it is composed. The purpose of the Nine Layer Pyramid Model Questionnaire for Emotional Intelligence is to measure emotional intelligence and to examine how well 
each person holds each level. The results can show the lowest acquisitions to intervene to increase the specific abilities / skills.

Although it is difficult to provide all the psychometric evidence for a new measure in one study, the results of the present research are encouraging. A remarkable attempt was made for the items of the questionnaire to choose the right words carefully after many changes to convey the desired meaning precisely and for the questionnaire to be readable. The research activity should be continued with multiple studies with different and larger samples and a variety of theoretically relevant criteria. Something else that should be taken seriously in the results through self-reports is the tendency sometimes of the participants to give socially desirable responses, to agree with statements, even have a false insight about their social and emotional skill in depth and not be quite objective and accurate in assessing those skills [53,54]. In the specific measurement some of the measurements showed that teachers possess more some levels of emotional intelligence pyramid model that are high in the hierarchy and less some others that are lower in the pyramid. The specific result as well as the objectivity of the answers on the part of the respondents, should be examined in future measurements.

The Nine Layer Pyramid Model Questionnaire for Emotional Intelligence can be used to evaluate the EI and monitor the development of the nine levels of the pyramid. Moreover, prospective studies whose purpose is to test its reliability and validity on bigger and diverse samples can be carried out and investigate correlation between the EI and other variables, to reveal EI's impacts on them. The Nine Layer Pyramid Model Questionnaire for Emotional Intelligence has been developed as an alternative measure of emotional intelligence of adults to use for scientific and practical purposes in many sectors.

\section{References}

[1] Costa, A., \& Faria, L. (2015). The impact of emotional intelligence on academic achievement: A longitudinal study in Portuguese secondary school. Learning and Individual Differences, 37, 38-47. https://doi.org/10.1016/j.lindif.2014.11.011

[2] MacCann, C., Jiang, Y., Brown, L. E., Double, K. S., Bucich, M., \& Minbashian, A. (2020). Emotional intelligence predicts academic performance: A meta-analysis. Psychological Bulletin, 146(2), 150. https://doi.org/10.1037/bul0000219

[3] Guerra-Bustamante, J., León-del-Barco, B., Yuste-Tosina, R., López-Ramos, V. M., \& Mendo-Lázaro, S. (2019). Emotional intelligence and psychological well-being in adolescents. International journal of environmental research and public health, 16(10), 1720. https://doi.org/10.3390/ijerph16101720

[4] Sánchez-Álvarez, N., Extremera, N., \& Fernández-Berrocal, P. (2016). The relation between emotional intelligence and subjective well-being: A meta-analytic investigation. The Journal of Positive Psychology, 11(3), 276-285. https://doi.org/10.1080/17439760.2015.1058968

[5] Cejudo, J., Rodrigo-Ruiz, D., López-Delgado, M. L., \& Losada, L. (2018). Emotional intelligence and its relationship with levels of social anxiety and stress in adolescents. International journal of environmental research and public health, 15(6), 1073. https://doi.org/10.3390/ijerph15061073

[6] Fteiha, M., \& Awwad, N. (2020). Emotional intelligence and its relationship with stress coping style. Health Psychology Open, 7(2), 2055102920970416. https://doi.org/10.1177/ $\underline{2055102920970416}$ 
[7] Alegre, A., Pérez-Escoda, N., \& López-Cassá, E. (2019). The relationship between trait emotional intelligence and personality. Is trait EI really anchored within the big five, big two and big One Frameworks? Frontiers in psychology, 10, 866. https://doi.org/10.3389/ fpsyg.2019.00866

[8] Ruvalcaba-Romero, N. A., Fernández-Berrocal, P., Salazar-Estrada, J. G., \& GallegosGuajardo, J. (2017). Positive emotions, self-esteem, interpersonal relationships, and social support as mediators between emotional intelligence and life satisfaction. Journal of Behavior, Health \& Social Issues, 9(1), 1-6. https://doi.org/10.1016/j.jbhsi.2017.08.001

[9] Schutte, N. S., Malouff, J. M., Bobik, C., Coston, T. D., Greeson, C., Jedlicka, C., ... \& Wendorf, G. (2001). Emotional intelligence and interpersonal relations. The Journal of social psychology, 141(4), 523-536. https://doi.org/10.1080/00224540109600569

[10] Miao, C., Humphrey, R. H., \& Qian, S. (2017). A meta-analysis of emotional intelligence and work attitudes. Journal of Occupational and Organizational Psychology, 90(2), 177-202. https://doi.org/10.1111/joop. 12167

[11] Schutte, N. S., \& Loi, N. M. (2014). Connections between emotional intelligence and workplace flourishing. Personality and Individual Differences, 66, 134-139. https://doi.org/10. 1016/j.paid.2014.03.031

[12] Kerr, B. A. (1991). Educating gifted girls. In Colangelo\& G.A. Davis (Eds.), Handbook of gifted education, Neeham Heights. pp. 402-415

[13] Sadri, G. (2012). Emotional intelligence and leadership development. Public Personnel Management, 41(3), 535-548. https://doi.org/10.1177/009102601204100308

[14] Martins, A., Ramalho, N., \& Morin, E. (2010). A comprehensive meta-analysis of the relationship between emotional intelligence and health. Personality and individual differences, 49(6), 554-564. https://doi.org/10.1016/j.paid.2010.05.029

[15] Puertas Molero, P., Zurita Ortega, F., Chacón-Cuberos, R., Castro Sánchez, M., Ramírez Granizo, I. A., \& González Valero, G. (2020). Emotional intelligence in the field of education: a meta-analysis. https://doi.org/10.14198/jhse.2018.13.proc2.01

[16] Mayer, J. D., Salovey, P., Caruso, D. R., \& Sitarenios, G. (2003). Measuring emotional intelligence with the MSCEIT V2. 0. Emotion, 3(1), 97. https://doi.org/10.1037/15283542.3.1.97

[17] Bar-On, R. (2006). The Bar-On model of emotional-social intelligence (ESI). Psicothema, $18,13-25$.

[18] Boyatzis, R. (2009), "Competencies as a behavioral approach to emotional intelligence", The Journal of Management Development, Vol. 28 No. 9, pp. 749-770. https://doi.org/10. 1108/02621710910987647

[19] Goleman, D. An EI-based theory of performance. In The Emotionally Intelligent Workplace: How to Selectfor, Measure, and Improve Emotional Intelligence in Individuals, Groups, and Organizations; John Wiley \& Sons:Hoboken, NJ, USA, 2001; Volume 1, pp. 27-44.

[20] Petrides, K. V., \& Furnham, A. (2001). Trait emotional intelligence: Psychometric investigation with reference to established trait taxonomies. European journal of personality, 15(6), 425-448. https://doi.org/10.1002/per.416

[21] Petrides, K. V. (2010). Trait emotional intelligence theory. Industrial and Organizational Psychology, 3(2), 136-139.

[22] Joshi, A., Kale, S., Chandel, S., \& Pal, D. K. (2015). Likert scale: Explored and explained. Current Journal of Applied Science and Technology, 396-403. https://doi.org/10.9734/ bjast $/ 2015 / 14975$

[23] Pérez, J.C., Petrides, K.V. \& Furnham, A. (2005). Measuring trait emotional intelligence. in R. Schulze and R.D. Roberts (Eds.). International Handbook of Emotional Intelligence. Cambridge: hogrefe \& huber.

[24] Śmieja, M., Orzechowski, J., \& Stolarski, M. S. (2014). TIE: An ability test of emotional intelligence. PLoS One, 9(7), e103484. https://doi.org/10.1371/journal.pone.0103484 
[25] Coskun, K., Öksüz, Y., \& Y1lmaz, H. B. (2017). Ten years emotional intelligence scale (TYEIS): Its development, validity, and reliability. International Journal of Assessment Tools in Education, 4(2).

[26] Parker, J. D., Saklofske, D. H., Shaughnessy, P. A., Huang, S. H., Wood, L. M., \& Eastabrook, J. M. (2005). Generalizability of the emotional intelligence construct: A cross-cultural study of North American aboriginal youth. Personality and individual differences, 39(1), 215-227. https://doi.org/10.1016/j.paid.2005.01.008

[27] Drigas, A. S., \& Papoutsi, C. (2018). A new layered model on emotional intelligence. Behavioral Sciences, 8(5), 45.

[28] Jang, D., Elfenbein, H.A., 2015. Emotion, Perception and Expression of. In: James D.Wright (editor-in-chief), International Encyclopedia of the Social \& Behavioral Sciences, 2nd edition, Vol 7. Oxford: Elsevier. pp. 483-489

[29] Mitchell, D.G.; Greening, S.G. Conscious perception of emotional stimuli: Brain mechanisms. Neuroscientist 2012,18, 386-398. https://doi.org/10.1177/1073858411416515

[30] Okon-Singer, H.; Lichtenstein-Vidne, L.; Cohen, N. Dynamic modulation of emotional processing.Biol. Psychol.2013,92, 480-491 https://doi.org/10.1016/j.biopsycho.2012.05.010

[31] Keltner, D., Sauter, D., Tracy, J., \& Cowen, A. (2019). Emotional expression: Advances in basic emotion theory. Journal of nonverbal behavior, 1-28. https://doi.org/10.1007/s10919019-00293-3

[32] Adolphs, R. (2003). Cognitive neuroscience of human social behaviour. Nature Reviews Neuroscience, 4(3), 165-178. https://doi.org/10.1038/nrn1056

[33] Aviezer, H., Hassin, R. R., Ryan, J., Grady, C., Susskind, J., Anderson, A., ... \& Bentin, S. (2008). Angry, disgusted, or afraid? Studies on the malleability of emotion perception. Psychological science, 19(7), 724-732. https://doi.org/10.1111/j.1467-9280.2008.02148.x

[34] Chan, V. (2009). The perception and recognition of emotions and facial expression. University of Toronto Journal of Undergraduate Life Sciences, 3(1).

[35] Blakemore, T., \& Agllias, K. (2019). Student reflections on vulnerability and self-awareness in a social work skills course. Australian Social Work, 72(1), 21-33. https://doi.org/ 10.1080/0312407x.2018.1516793

[36] Chinnery, S. A., \& Beddoe, L. (2011). Taking active steps towards the competent use of self in social work. Advances in Social Work and Welfare Education, 13(1), 89.

[37] Sunindijo, R.Y.; Hadikusumo, B.H.; Ogunlana, S. Emotional intelligence and leadership styles in constructionproject management.J. Manag. Eng.2007,23, 166-170. https://doi. org/10.1061/(asce)0742-597x(2007)23:4(166)

[38] Mischel, W., DeSmet, A., \& Kross, E. (2014). Self-regulation in the service of conflict resolution. In P. Coleman, M.Deutsch, \& E. Marcus (Eds.), The handbook of conflict resolution: Theory and practice(3rd ed.). San Francisco, CA: Jossey-Bass.

[39] Ioannidou, F.; Konstantikaki, V. Empathy and emotional intelligence: What is really about?Int. J. Caring Sci.2008,1, 118

[40] Drigas, A., \& Mitsea, E. (2020). The 8 Pillars of Metacognition. International Journal of Emerging Technologies in Learning (iJET), 15(21), 162-178. https://doi.org/10.3991/ijet. v15i21.14907

[41] Khan, S., Gagné, M., Yang, L., \& Shapka, J. (2016). Exploring the relationship between adolescents' self-concept and their offline and online social worlds. Computers in Human Behavior, 55, 940-945. https://doi.org/10.1016/j.chb.2015.09.046

[42] Potworowski, G., \& Kopelman, S. (2007). Developing evidence-based expertise in emotion management: Strategically displaying and responding to emotions in negotiations. Ross School of Business Paper, (1099). https://doi.org/10.2139/ssrn.1020626

[43] Gopinath, R. (2020). Confirmator Factor Analysis in Self Actualization.

[44] Rogers, C. (1961). On Becoming a Person, Boston, Mass.: Houghton Mifflin 
[45] Gowan, J. C. (1972). Levels of Development and Accomplishment in Superior Male Adults. The Guidance and measurement of intelligence, development, and creativity, Northridge, California. California State University, pp. 205-217.

[46] Kerr, R., Garvin, J., Heaton, N., \& Boyle, E. (2006). Emotional intelligence and leadership effectiveness. Leadership \& Organization Development Journal. https://doi.org/10.1108/ 01437730610666028

[47] Lutz, C., \& White, G. M. (1986). The anthropology of emotions. Annual review of anthropology, 15(1), 405-436.

[48] Huitt, W. (2001). Motivation to learn: An overview. Educational psychology interactive, 12.

[49] Huitt, W. (2007). Maslow's hierarchy of needs. Educational psychology interactive, 23.

[50] Stellar, J. E., Gordon, A. M., Piff, P. K., Cordaro, D., Anderson, C. L., Bai, Y., Maruskin, L. A., \& Keltner, D. (2017). Self-transcendent emotions and their social functions: Compassion, gratitude, and awe bind us to others through prosociality. Emotion Review, 9(3), 200207. https://doi.org/10.1177/1754073916684557

[51] Ratcliffe, M. (2017). Grief and the Unity of Emotion. Midwest Studies in Philosophy, 41, 154-174. https://doi.org/10.1111/misp.12071

[52] Adamos, M. (2007). The Unity of Emotion: An Unlikely Aristotelian Solution. The Journal of Mind and Behavior, 28(2), 101-114.

[53] McDonald, J. D. (2008). Measuring personality constructs: The advantages and disadvantages of self-reports, informant reports and behavioural assessments. Enquire, 1(1), 119.

[54] Paulhus, D. L., \& Vazire, S. (2007). The self-report method. Handbook of research methods in personality psychology, 1(2007), 224-239.

\section{$7 \quad$ Authors}

Athanasios Drigas is a Research Director at IIT-N.C.S.R. Demokritos. He is the Coordinator of Telecoms Lab and founder of Net Media Lab since 1996. From 1990 to 1999 he was the Operational manager of the Greek Academic network. He has been the Coordinator of Several International Projects, in the fields of ICTs, and eservices (elearning, e-psychology, e-government, e-inclusion, e-culture etc). He has published more than 300 articles, 7 books, 25 educational CD-ROMs and several patents. He has been a member of several international committees for the design and coordination of Network and ICT activities and of international conferences and journals. Also, he has accepted several distinctions for his work (articles, projects, patents).

Chara Papoutsi is a PhD Candidate in Information and Communication Systems Engineering at the University of the Aegean in Samos, Greece. She holds a Master's degree in Applied Pedagogy at the National and Kapodistrian University of Athens. She is a teacher in a primary school. She has publications on empathy and emotionalintelligence and she is also with NCSR DEMOKRITOS, Institute of Informatics and Telecommunications, Net Media Lab, Athens, Greece, papoutsi.xara@yahoo.com

Article submitted 2021-03-19. Resubmitted 2021-04-12. Final acceptance 2021-04-12. Final version published as submitted by the authors. 